\title{
STUDY ON EFFECT OF PHYSICOCHEMICAL PARAMETERS ON GROWTH OF FUSARIUM EQUISETI (MTCC9658)
}

KEY WORDS: Biomass, Dextrose, Fusarium equiseti Microorganisms, Nutrients

\section{Arshi Naaj}

Afsana

Dr. Ajay Kumar

Srivastava*

\section{Dr. Madhulika}

Singh
Research Scholar,Department of Botany, Ranchi University, Ranchi (Jharkhand).

Head of the Department of Botany, St. Xavier's College, Ranchi (Jharkhand). *Corresponding Author

Senior faculty, Department of Botany, St.Xavier's College, Ranchi (Jharkhand).

The microorganisms like fungi proliferate in different environmental and ecological conditions depending upon the availability of nutrients and the form of nutrient that they absorb. In addition to this the physical conditions like temperature, pH, salinity and light etc. also effect the growth and biomass production of fungal species. The present study was carried out to determine the effect of variation in physical and chemical parameters on growth and biomass production of the fungal strain Fusarium equiseti (MTCC9658). A maximum biomass yield of $12.24 \mathrm{~g} / \mathrm{L}$ at $\mathrm{pH} 5$ and temperature of $30^{\circ} \mathrm{C}$ was recorded; and minimum of $5.21 \mathrm{~g} / \mathrm{L}$ at pH 9 and temperature of $25^{\circ} \mathrm{C}$. The observations clearly indicate that $\mathrm{pH} 9$ and above did not support higher biomass production at any of the temperatures, while pH 5 to $\mathrm{pH} 6$ supports higher dry biomass production in all temperature ranges applied. The different carbon and nitrogen sources used in the medium corresponded to variation in growth of the strain. Dextrose in combination with Yeast extract as nitrogen source was best for biomass production.

\section{INTRODUCTION}

The microorganisms thrive in different environmental and ecological condition differently. Their growth depends on the nutritional elements present in the surrounding they proliferate in, synthetic medium or, development on host and also the absorbable forms of nutritional elements. The different carbon and nitrogen sources comprising a synthetic culture medium have great effect on biomass production of the microorganisms. The culture medium composition has immense effect on the production of the extracellular proteins, carbohydrates, secondary metabolites and other valuable compounds. Fusarium spp. are producers of many mycotoxins and are responsible for causing frequent contaminations of cereal and fruit rots too. Since they produce type A trichothecenes, a type of sesquiterpenoid differing from other trichothecenes because they do not have a carbonyl group in position C8. Chromic exposure to trichothecenes causes weight loss, bloody diarrhea and pathological changes in liver and stomach as well as stunted growth and reproductive defects (Gil- Serna et al, 2014). On the other hand few species have been investigated for useful natural products too. The marine fungi, fungal endosymbionts and lichens are being investigated for natural colorant sources. In one of the studies by Dawoud et al in 2020, a yellow colored pigment was produced from endolichenic Bacillus sp. that was isolated from a lichen known as Dirinaria aegialita. The bacterial strain characterized as Bacillus gibsonii was able to produce yellow pigments in Luria- Bertani medium. It was isolated and partially purified using thin layer chromatography and FTIR and GC-MS analysis showed its possibility of carotenoid formation. Additionally the pigment exhibited antifungal activity against 3 fungal pathogens: $R$. solani, F oxysporum and $S$. rolfsi, and antioxidant properties too.

Fusarium equiseti is synonymously also known as Gibberella intricans Wollenw. 1930 (Schoch et al, 2020). F. equiseti has not been much investigated for its brighter prospects in terms of industrial and biotechnological research. The undertaken study has been carried out to investigate the effect of variation in physical and chemical parameters on the growth and biomass production of Fusarium equiseti.

The availability of nutrients and essential matter for growth provided by the host to the pathogenic fungi are important tools to study the host pathogen interaction and their control strategy. The in vitro studies of cultivating the fungal pathogens in a number of manipulated synthetic medium helps to know the effect of the physical and chemical parameters on their growth and sporulation. A number of physical and chemical factors are there that affect the growth and sporulation of different fungi. Physical factors liketemperature, $\mathrm{pH}$, light and aeration etc. (Dhingra and Sinclair, 1995) and chemical factors that are basically the chemical composition of the culture media like- carbon sources, nitrogen sources, mineral salts/ions and other undefined supplements. In one of the studies by Ramteke \& Kamble (2011) sucrose was also considered the best carbon source for the strain Fusarium solani. In another study by Sharmin et al. (2012) it was found that Peptone and Sucrose were most suitable nitrogen and carbon source for Fusarium oxysporum. Mailto and coworkers in 2017, found that temperature and pH affected the spore formation and spore size in pathogenic fungi Fusarium oxysporum isolated from Chickpea. They found that the temperature of $30^{\circ} \mathrm{C}$ and $\mathrm{pH}$ from 6 to 7 supported higher sporulation and dry mycelia weight yield.

\section{MATERIALS AND METHODS}

\section{Revival of fungal cultures}

Fungal strain Fusarium equiseti (MTCC9658) acquired from Microbial Type Culture Collection and Gene Bank (MTCC) Chandigarh, India; was revived and maintained on Potato Dextrose Agar medium (PDA- Potato infusion $200 \mathrm{~g} / \mathrm{L}$, Dextrose $20 \mathrm{~g} / \mathrm{L}$ and Agar $20 \mathrm{~g} / \mathrm{L})$.

\section{Effect of $\mathrm{pH}$ and temperature}

To study the effect of $\mathrm{pH}$ and temperature on growth and biomass production of Fusarium (MTCC9658), the fungal spores in concentration of $10^{6}$ spores $/ \mathrm{ml}$ was inoculated in Potato Dextrose Broth (PDB) medium. The $\mathrm{pH}$ was set ranging from 3 to 9 , and each set was incubated at three different temperatures i.e. at $25^{\circ} \mathrm{C}, 30^{\circ} \mathrm{C}$ and $35^{\circ} \mathrm{C}$. The cultures were incubated for 4 weeks for growth. Each set of experiment was performed in triplicates and observations recorded as average of three values.

Effect of different carbon, nitrogen sources and N/C ratio The fungal strain Fusarium equiseti was cultured in varying nitrogen to carbon ratio (N: C) as nutrient in the ratio- 1:6, 1:4 and $1: 2$. The 3 carbon sources namely dextrose, sucrose and 
lactose, each in combination with four different nitrogen sources -Yeast Extract, Peptone, Potassium nitrate $\left[\mathrm{KNO}_{3}\right]$ and Ammonium Sulphate $\left[(\mathrm{NH} 4)_{2} \mathrm{SO}_{4}\right]$ supplemented in basic PDA medium, in above mentioned three different ratios were used to optimize the culture media for growth and biomass production in submerged culture condition. Each set of experiment was performed in triplicates and observations recorded as average of three values.

\section{RESULTS AND DISCUSSION}

\section{Effect of pH and temperature}

Fusarium equiseti (MTCC9658) cultivated at $25^{\circ} \mathrm{C}$ temperature, the maximum biomass production of $8.98 \mathrm{~g} / \mathrm{L}$ was recorded at $\mathrm{pH} 6$ while minimum of $5.2 \mathrm{lg} / \mathrm{L}$ at $\mathrm{pH} 9$ (Table 1). At $30^{\circ} \mathrm{C}$ the highest dry biomass produced was $12.24 \mathrm{~g} / \mathrm{L}$ at $\mathrm{pH} 5$ and lowest of $6.01 \mathrm{~g} / \mathrm{L}$ at $\mathrm{pH} 9$. A maximum biomass yield of $9.2 \mathrm{lg} / \mathrm{L}$ and minimum of $5.39 \mathrm{~g} / \mathrm{L}$ at $\mathrm{pH} 6$ and $\mathrm{pH} 9$ respectively was produced at $35^{\circ} \mathrm{C}$. The observations clearly indicate that $\mathrm{pH} 9$ did not support higher biomass production at any of the temperatures, while pH 5 to 6 supports higher dry biomass production in all temperature ranges applied (Fig l).

Effect of different carbon, nitrogen sources and N/C ratio: DEXTROSE: As carbon source Dextrose was used in combination with 4 different nitrogen sources supplemented to basic PDB medium in three different $\mathrm{N}: \mathrm{C}$ ratios, resulted in highest biomass production of $10.76 \mathrm{~g} / \mathrm{L}$ at $\mathrm{N}: \mathrm{C}=1: 6$ with Yeast extract as nitrogen source and lowest of $4.22 \mathrm{~g} / \mathrm{L}$ with Ammonium Sulphate as nitrogen source in the ratio $\mathrm{N}: \mathrm{C}=1: 2$.

SUCROSE: When Sucrose was supplemented to basic PDB medium in place of Dextrose with 4 different nitrogen sources in 3 ratios, it showed maximum dry biomass yield of $8.64 \mathrm{~g} / \mathrm{L}$ with Peptone as nitrogen source in the ratio $\mathrm{N}: \mathrm{C}=1: 6$ whereas a minimum of $3.20 \mathrm{~g} / \mathrm{L}$ with yeast extract in the ratio $\mathrm{N}: \mathrm{C}=1: 2$. There was no growth seen at all in Ammonium Sulphate in any ratio with Sucrose.

LACTOSE: When Lactose was supplemented to basic PDB medium in place of Dextrose with 4 different nitrogen sources in 3 ratios, highest yield of $6.22 \mathrm{~g} / \mathrm{L}$ dry mycelia obtained at $\mathrm{N}: \mathrm{C}=1: 6$ with Yeast extract as nitrogen while minimum biomass of $2.14 \mathrm{~g} / \mathrm{L}$ with Potassium Nitrate as nitrogen source at ratio $\mathrm{N}: \mathrm{C}=1: 2$ (Fig 2).

\begin{tabular}{|l|c|c|c|}
\hline $\mathbf{p H}$ & $\begin{array}{c}\text { Mycelial weight in } \\
\mathbf{g} / \mathbf{L} \text { at } 25^{\circ} \text { celsius }\end{array}$ & $\begin{array}{c}\text { Mycelial weight } \\
\text { in } \mathbf{g} / \mathbf{L} \text { at } \mathbf{3 0}^{\circ} \\
\text { celsius }\end{array}$ & $\begin{array}{c}\text { Mycelial weight } \\
\text { in } \mathbf{g} / \mathbf{L} \text { at } \mathbf{3 5}^{\circ} \\
\text { celsius }\end{array}$ \\
\hline $\mathrm{pH}$ & 6.12 & 8.64 & 8.51 \\
\hline $\mathrm{pH} 4$ & 6.11 & 11.42 & 7.23 \\
\hline $\mathrm{pH} 5$ & 8.62 & $\mathbf{1 2 . 2 4}$ & 8.65 \\
\hline $\mathrm{pH} 6$ & $\mathbf{8 . 9 8}$ & 6.33 & $\mathbf{9 . 2 1}$ \\
\hline $\mathrm{pH}$ & 7.36 & 7.35 & 8.27 \\
\hline $\mathrm{pH} 8$ & 7.25 & 7.65 & 6.66 \\
\hline $\mathrm{pH}$ & $\mathbf{5 . 2 1}$ & $\mathbf{6 . 0 1}$ & $\mathbf{5 . 3 9}$ \\
\hline
\end{tabular}

Table.1.Dry mycelial weight at the end of 4 weeks recorded at 3 different temperatures with $\mathrm{pH}$ ranging from $\mathrm{pH} 3$ to $\mathrm{pH} 9$

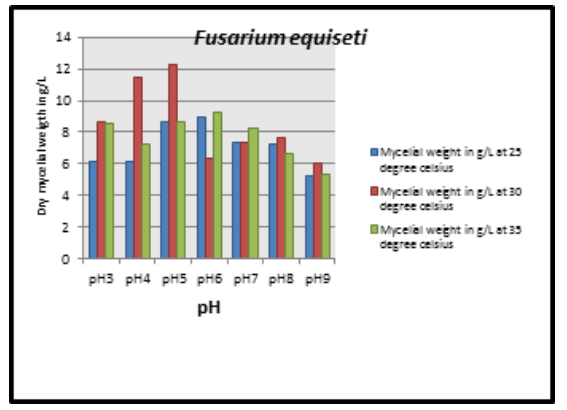

Fig. 1 Graph showing dry mycelial weight at the end of 4 weeks recorded at 3 different temperatures with $\mathrm{pH}$ ranging from $\mathrm{pH} 3$ to $\mathrm{pH} 9$

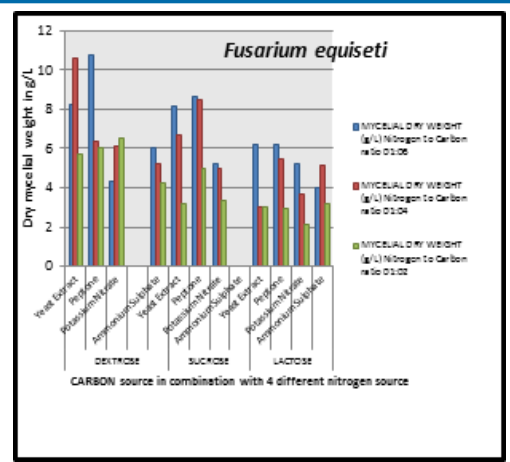

Fig. 2 Dry mycelial weight at the end of 4 weeks recorded in with 3 different carbon sources in combination with 4 different nitrogen sources used in 3 different $N$ : $C$ ratio (ie. $1: 6,1: 4$ and $1: 2$ )

\section{CONCLUSIONS}

In the present study two physical parameters that are $\mathrm{pH}$ and temperature were studied. The investigation shows that the strain Fusarium equiseti (MTCC9658) gave high dry biomass yield at $\mathrm{pH}$ range of 5 to 6 , and decrease in biomass was observed as the $\mathrm{pH}$ decreased to $\mathrm{pH} 3$ and also upon increasing towards neutral and then to $\mathrm{pH}$ 9. Temperature of $30^{\circ} \mathrm{C}$ was best for the strain while at $25^{\circ} \mathrm{C}$ dry biomass production was moderate. The best $\mathrm{pH}$ and temperature combination to produce high biomass was $\mathrm{pH} 5$ at $30^{\circ} \mathrm{C}$.

In the undertaken study the chemical parameters examined for the growth and biomass production of Fusarium equiseti (MTCC9658) using basic PotatoDextrose Agar medium modified by adding other carbon and nitrogen sources revealed that Dextrose was the best carbon source producing high yield of dry biomass, although the strain was able to utilise sucrose and lactose as well but gave lesser growth as compared to dextrose. The combined effects of carbon and nitrogen sources were also analysed and it indicated that Yeast extract and Peptone were best nitrogen sources, Yeast extract being on top. Ammonium sulphate and Potassium nitrate gave lesser dry biomass yield with all carbon sources in all $\mathrm{N}$ : $\mathrm{C}$ ratios. Sucrose in combination with Ammonium sulphate produced no spores at all in submerged culture. Lactose with Yeast among different nitrogen sources gave high dry biomass yield. The results obtained in this study are in agreement with one of the studies by Maitlo et al. (2017) that depicts dextrose as best carbon source for the growth of pathogenic fungi Fusarium oxysporum isolated from Chickpea.

\section{ACKNOWLEDGEMENT}

Current study was financially supported by Council of Scientific \& Industrial Research (CSIR) research grant fellowship (JRF).

\section{REFERENCES}

[1] Dawoud, T.M., Alharbi, N.S, Theruvinthalakal, A.M., Thekkangil, A. Kadaikunnan, S., Khaled, J.M., Almanaa, T.N., Sankar, K., Innasimuthu, G.M., Alanzi K.F. and Rajaram, S.K. (2020) Characterization and antifungal activity of the yellow pigment produced by a Bacillus sp. DBS4 isolated from the lichen Dirinaria agealita. Saudi Journal of Biological Sciences 27: 1403- 1411.

[2] Dhingra, O.D. and Sinclair, J.B. (1995). Basic Plant Pathology Methods. CRS Press, Inc. Boca Raton, Florida, USA

[3] Gil- Serna, J., Vazquez, C., Gonzalez- Jean, M.T. and Patino, B. (2014) MYCOTOXINS- toxicology. Encyclopedia of food microbiology $2^{\text {nd }}$ edition, 887-892.

[4] Maitlo, S., Rajput, A. Q. Syed, R.N., Khanzada, M.A., Rajput N.A. and Lodhi, A.M. (2017). Influence of physiological factors on vegetative growth and sporulation of Fusarium oxysporum f.sp. Ciceris. Pak.J.Bot. 49:311-316.

[5] Ramteke, P.K. and Kamble,S.S. (2011).Physiological studies in Fusarium solani causing rhizome rot of ginger (Zingiber officinale Rocs). The Bioscan, 6(2): 195-197.

[6] Schoch C.L., et al. NCBI taxonomy: a comprehensive update on curation, resources and tools. Database (Oxford). 2020:baaa062

[7] Sharmin, S., Bhuiyan, K.A., Uddin, M.R. and Anwar, M.B. (2012). Influence of some growth factors on in-vitro growth of Fusarium oxysporum f.sp. phaseoli causing seedling mortality of bush bean. Bangladesh J. Plant Pathol. 28(1\&2): $9-14$. 